\title{
KONTESTASI PANDANGAN BUDAYA DALAM SEJARAH KONGRES KEBUDAYAAN DI INDONESIA
}

(Studi Analisis Teks pada Sebelas Makalah Kongres Kebudayaan di Indonesia Tahun 1991)

\author{
Hendi Roy
}

Sosiologi, Fakultas Ilmu Sosial, Universitas Negeri Jakarta

hendiroyy@gmail.com

Diterima Redaksi: 26-04-2021 | Selesai Direvisi: 25-05-2021 | Diterbitkan Online 04-06-2021

\begin{abstract}
This study aims to explain how the contestation of cultural views that occurred at the 1991 Indonesian Cultural Congress. This study uses a qualitative method with a literature study approach and cultural analysis techniques in the text. The text will also be analyzed with the sociological theory of culture according to Raymond Williams to see the process of production and reproduction of culture in the text. The researcher used eleven texts from a total of eighty-nine texts. This study concludes that the contestation of views can be seen based on three characteristics, namely related to the discourse of national development, the modernization of Indonesian culture, and the role of culture in the sector of community life. The relationship between the congress and national cultural politics was shown by the existence of ideas that supported the New Order cultural discourse and criticized it. The 1991 Indonesian Cultural Congress legitimized the national cultural politics of the New Order based on the role of the Directorate of Culture and TMII, the interpretation of undeveloped social formations of society, and the mode of production with a capitalist system. As a tradition that has been carried out in every history of cultural development, congress has always reproduced the values of cultural democratization. In supporting the national cultural politics of the New Order, several speakers use the term development, maintenance and fostering of a culture that is distinctive with dominant cultural discourses. Meanwhile, those who criticized him highlighted the reality of people's cultural life with the discourse of national development.
\end{abstract}

Keywords: culture, cultural congress, new order, text analysis, national cultural politics. Abstrak
Penelitian ini bertujuan untuk menjelaskan bagaimana kontestasi pandangan budaya
yang terjadi pada peristiwa Kongres Kebudayaan Indonesia Tahun 1991. Penelitian ini
menggunakan metode kualitatif dengan pendekatan studi kepustakaan dan teknik analisis
kebudayaan dalam teks. Teks juga akan dianalisis dengan teori sosiologi kebudayaan
menurut Raymond Williams untuk melihat proses produksi dan reproduksi budaya dalam
teks. Peneliti menggunakan sebelas teks dari total delapan puluh sembilan teks. Studi ini
menyimpulkan bahwa kontestasi pandangan dapat dilihat berdasarkan tiga karakteristik,
yaitu terkait wacana pembangunan nasional, modernisasi kebudayaan Indonesia, dan
peran kebudayaan dalam sektor kehidupan masyarakat. Hubungan antara kongres dan
politik kebudayaan nasional ditunjukkan dengan adanya gagasan yang mendukung
diskursus budaya Orde Baru dan mengkritiknya. Kongres Kebudayaan Indonesia Tahun
1991 melegitimasi politik kebudayaan nasional Orde Baru berdasarkan peran Direktorat
Kebudayaan dan TMII, penafsiran atas formasi sosial masyarakat yang terbelakang, dan
mode produksi dengan sistem kapitalisme. Sebagai sebuah tradisi yang dilakukan dalam 
setiap sejarah perkembangan budaya, kongres senantiasa mereproduksi nilai demokratisasi kebudayaan. Dalam mendukung politik kebudayaan nasional Orde Baru, beberapa pemakalah menggunakan istilah pengembangan, pemeliharaan dan pembinaan budaya yang khas dengan wacana kebudayaan dominan. Sedangkan yang mengkritiknya menyoroti realitas kehidupan kultural masyarakat dengan wacana pembangunan nasional.

Kata Kunci: kebudayaan, kongres kebudayaan, orde baru, analisis teks, politik kebudayaan nasional.

\section{Pendahuluan}

Kongres Kebudayaan adalah salah satu forum yang bersifat formal dalam membahas dinamika perkembangan masyarakat Indonesia terutama dalam bidang kebudayaan. Kongres Kebudayaan merupakan upaya rekonsiliasi dari perdebatan kebudayaan yang terjadi dan sebagai cara membangun dialektika akan diskursus kebudayaan. Kongres Kebudayaan merupakan suatu peristiwa budaya yang amat penting maknanya, tidak hanya bagi kebudayaan kita yang beranekaragam (multikultur), tetapi juga bagi usaha memperkukuh persatuan bangsa Indonesia yang terdiri dari berbagai suku bangsa (multietnik) (Nunus Supardi, 2007: 3).

Menurut data yang berhasil dihimpun, Kongres Kebudayaan pertama diselenggarakan tahun 1918 di Surakarta. Setelah itu diikuti dengan kongres-kongres berikutnya, yaitu: Kongres Kebudayaan tahun 1919 di Surakarta, tahun 1924 di Yogyakarta, tahun 1926 di Surabaya, tahun 1929 di Surakarta, dan tahun 1937 di Bali. Setelah Indonesia merdeka, Kongres Kebudayaan diselenggarakan tahun 1948 di Magelang, kemudian disusul tahun-tahun: 1951 di Bandung, tahun 1954 di Surakarta, 1957 di Bali, 1960 di Bandung, 1991 di Jakarta dan yang baru saja dilaksanakan tahun 2003 di Buktitinggi (Nunus Supardi, 2007: 5).

Sepanjang diadakannya Kongres Kebudayaan di Indonesia, salah satu Kongres Kebudayaan yang menarik banyak perhatian kalangan intelektual, budayawan dan masyarakat adalah peristiwa Kongres Kebudayaan pada tahun 1991 di Jakarta. Hal ini disebabkan sempat terhentinya pembahasan budaya dalam tingkat nasional selama 31 tahun. Sebagai efek dari pola pemerintahan dan berbagai tindakannya yang represif dengan dalih menjaga stabilitas negara, banyak kalangan yang meragukan pelaksanaan kongres ini, muncul istilah - istilah sinis seperti; kongresnya baju Korpri, kongresnya baju safari, kongres pejabat pemerintah, kongres birokrasi, keputusan kongres sudah siap sebelum kongres dibuka, dan lain-lain (Nunus Supardi, 2007: 214). Hal ini dirasa tidak mengherankan dengan melihat bahwa rezim Orde Baru memang memantapkan posisinya dengan menyelaraskan bahkan menyeragamkan 
berbagai aspek dalam kehidupan masyarakat secara hegemonik dan represif untuk mendukung berbagai program yang diberlakukannya.

Tod Jones dalam bukunya Kebudayaan dan Kekuasaan di Indonesia: Kebijakan Budaya Selama Abad Ke-20 Hingga Era Reformasi (2015) pun menegaskan bahwa ada suatu kesinambungan berskala besar dalam kebijakan budaya pada seluruh masa Orde Baru. Suatu peristiwa yang menegaskan arah kebijakan budaya selama Orde Baru, sambil secara simultan menghubungkannya dengan zaman perjuangan kemerdekaan, adalah Kongres Kebudayaan IV pada tahun 1991. Kongres Kebudayaan IV tersebut bertema "Dari Seni hingga Pembangunan" dan, tidak mengherankan, tema itu menegaskan arah kebijakan budaya rezim Orde Baru dalam rekomendasinya meskipun terdapat pertentangan dari beberapa peserta (Tod Jones, 2015: 206). Menjadi sangat penting untuk melihat bagaimana sebuah proses historis dalam konteks kebudayaan Indonesia bersinggungan dengan kebutuhan atau agenda rezim yang berkuasa.

Secara sosiologis, Kongres Kebudayaan adalah upaya untuk melakukan produksi dan reproduksi kebudayaan termasuk gagasan, kebijakan, dan strategi yang dibangun dalam mengatasi problema dan kebutuhan kultural masyarakat. Aktivitas kultural dalam masyarakat tidak terlepas dari kehadiran ruang atau institusi yang memberikan akses bagi setiap masyarakat yang secara aktif melakukan produksi dan reproduksi kebudayaannya.

Penelitian ini akan melakukan kajian mengenai peristiwa sejarah Kongres Kebudayaan, secara spesifik adalah Kongres Kebudayaan tahun 1991. Pemilihan Kongres Kebudayaan tahun 1991 berdasar pada perkembangan pandangan kebudayaan yang melihat konteks sosial politik masyarakat - disaat rezim Orde Baru berkuasa - dengan memperhatikan juga kebutuhan agenda politis yang berimplikasi pada pelaksanaan kongres. Sebagai upaya untuk menggambarkan dinamika perkembangan diskursus kebudayaan dan hubungannya dengan konteks sosial politik, penelitian ini secara khusus akan mengkaji teks-teks dalam bentuk makalah kebudayaan untuk mendapatkan gambaran dari beragamnya pandangan sebagai respon serta gagasan bagi kebudayaan Indonesia.

\section{Metode Penelitian}

Penelitian ini dilakukan dengan metode kualitatif dan disesuaikan dengan metode pengumpulan data yang akan digunakan, yaitu penelitian kepustakaan (library research). Metode kualitatif dipilih oleh peneliti karena memiliki beberapa keunggulan bila digunakan dalam penelitian ini. Pertama, pendekatan kualitatif lebih mudah jika berhadapan langsung dengan realitas. Kedua, pendekatan ini menyajikan secara langsung hakikat hubungan antara peneliti dan objek penelitian. Ketiga, pendekatan ini mampu menggali data lebih dalam karena dapat dianalisa secara deskriptif ditambah dengan referensi lain dari literatur yang didapatkan. 
Untuk pengumpulan data digunakan pendekatan historis dengan beberapa tahapan yang perlu dilakukan. Tahap pertama adalah heuristik, pengumpulan sumber-sumber data primer dan sekunder, sumber primer dalam penelitian ini adalah Laporan Hasil Penyelenggaraan Kongres Kebudayaan tahun 1991 dan berbagai makalah yang dijadikan gagasan atau pandangan mengenai kebudayaan dan bahan diskusi dalam bentuk bunga rampai yang terbagi menjadi lima jilid sesuai dengan sub-tema Kongres Kebudayaan tahun 1991. Sumber sekunder adalah buku-buku, majalah, surat kabar, artikel dan jurnal ilmiah yang relevan dengan penelitian ini, seperti yang dimuat dalam surat kabar Pikiran Rakyat, Harian Jawa Post, dan Suara Pembaruan. Tahapan kedua adalah kritik sumber, dalam tahapan ini peneliti melakukan proses kritik terhadap sumber-sumber data untuk mendapatkan penilaian yang objektif dalam melihat subtansi dari literatur terkait dan memilih literatur mana saja yang sekiranya sesuai untuk dapat digunakan dengan penelitian. Tahapan ketiga adalah interpretasi atau penafsiran, dalam tahapan ini peneliti mencoba menghindari subjektifitas dan berusaha objektif terhadap fakta-fakta yang terdapat dalam sumber data penelitian. Tahapan yang terakhir adalah histiografi, dalam tahapan ini peneliti mencoba untuk merekonstruksi ulang kronologis dari peristiwa sejarah Kongres Kebudayaan khususnya ditahun 1991 dan memberikan penjelasan baru terkait pelaksanaannya yang berhubungan dengan perkembangan diskursus kebudayaan dalam masyarakat.

Dari pengumpulan data tersebut, peneliti memilih sebelas teks dari total depalan puluh sembilan teks yang dimuat dalam lima jilid bunga rampai makalah Kongres Kebudayaan Indonesia Tahun 1991. Sebelas teks tersebut dipilih berdasarkan kualifikasi abstrak atas konsep kunci dalam pendekatan cultural studies yang terdiri atas, culture and power, culture as “value”, culture as policy, culture as cohesion, culture as standarization, culture as language or understanding (Richard Johnson, dkk, 2004: 10-14). Dengan demikian, peneliti dapat memetakan pandangan budaya yang konstrukstif dan dekonstruktif dengan wacana politik kebudayaan nasional Orde Baru dalam konteks pembangunan nasional.

Untuk melakukan analisis mendalam dari teks-teks yang dijadikan subjek dalam penelitian, dalam hal ini peneliti menggunakan perspektif cultural studies sebagai alat bantu analisa. Cultural Analysis of Text akan digunakan untuk membandingkan isi teks yang disampaikan dalam bentuk makalah kebudayaan. Untuk membandingkan isi teks tersebut ada tiga poin penting yang disoroti, yaitu, pesan dalam teks, situasi sosial politik, dan interpretasi pembaca. Proses perbandingan dilakukan dengan merujuk kepada literatur yang membahas kondisi sosial, politik, dan budaya pada masa pemerintahan Orde Baru, hal ini dilakukan untuk 
menghindari simplifikasi dan membangun interpretasi baru terkait permasalahan budaya yang dikemukakan oleh para tokoh.

Setelah menjelaskan kontestasi pandangan para tokoh melalui makalah kebudayaan yang dipilih, peneliti akan menganalisa secara keseluruhan terkait pelaksanaan Kongres Kebudayaan Tahun 1991 dengan politik kebudayaan nasional. Analisa ini akan dititikberatkan kepada Teori Sosiologi Kebudayaan menurut Raymond Williams yang berfokus pada proses produksi dan reproduksi kebudayaan.

\section{Hasil dan Pembahasan}

Bagian ini akan menjelaskan temuan penelitian terkait konstestasi pandangan budaya dalam Kongres Kebudayaan Indonesia Tahun 1991, serta hubungannya dengan politik kebudayaan nasional Orde Baru. Pada bagian pertama adalah terkait konteks sosio-historis Kongres Kebudayaan Indonesia Tahun 1991. Dibagian kedua, diuraikan mengenai profil pemakalah dalam Kongres Kebudayaan Indonesia tahun 1991. Bagian ketiga, membahas kategorisasi dari sebelas teks makalah yang dipilih dalam penelitian ini terkait konstruksi dan dekonstruksi atas diskursus budaya Orde Baru. Selanjutnya bagian keempat, mengenai keterkaitan politik kebudayaan nasional dengan Kongres Kebudayaan Indonesia Tahun 1991. Terakhir dibagian kelima, terkait kritik atas politik kebudayaan nasional dalam Kongres Kebudayaan Indonesia Tahun 1991.

\section{Konteks Sosio-Historis Pelaksanaan Kongres Kebudayaan Indonesia Tahun 1991}

Kongres Kebudayaan Tahun 1991 diselenggarakan pada 29 Oktober hingga 3 November 1991 di Taman Mini Indonesia lndah (TMII) Jakarta dengan menggunakan berbagai anjungan untuk sidang kelompok. Sidang pleno diselenggarakan di Sasono Langenbudhoyo. Kongres kebudayaan ini diikuti oleh kurang lebih 1000 peserta. Mereka terdiri atas tokoh masyarakat baik yang formal maupun non-formal, pemangku adat, ilmuwan, budayawan, dan beberapa pengamat dari negara-negara tetangga, seperti Malaysia, Brunei Darussalam, dan Australia (Departemen Pendidikan dan Kebudayaan, 1992: 19).

\section{Gambar 1}

\section{Logo Kongres Kebudayaan Indonesia Tahun 1991}

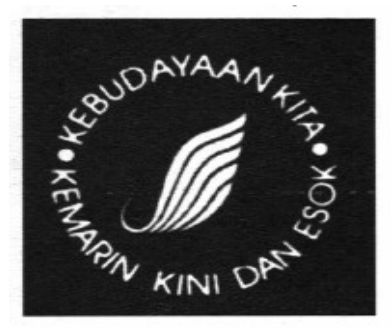


Sumber: Nunus Supardi, 2013.

Dalam urutan sejarah pelaksanaan kongres kebudayaan, Kongres Kebudayaan Indonesia Tahun 1991 masih diperdebatkan dalam persoalan penempatannya dalam kronologi pelaksanaan Kongres Kebudayaan di Indonesia. Menurut Nunus Supardi, dengan mengacu pada keseluruhan penyelenggaraan ajang pertemuan budaya setingkat nasional dan melibatkan banyak kalangan, kongres ini dimasukkan kedalam urutan ke-VI, Kongres Kebudayaan Tahun 1991 sebagai Kongres Kebudayaan VI (urutan versi baru) diselenggarakan setelah hampir 31 tahun lamanya setelah Kongres Kebudayaan V Tahun 1960 (Nunus Supardi, 2013: 128).

Untuk membangun sebuah argumentasi yang logis dan komprehensif mengenai latar belakang pelaksanaan Kongres Kebudayaan Indonesia Tahun 1991, sepertinya perlu diperhatikan beberapa peristiwa sejarah terutama yang sifatnya politis disekitar tahun-tahun pelaksanaan kongres yang pastinya memberikan pengaruh pada kongres tersebut. Dalam catatan sejarah, pelaksanaan Kongres Kebudayaan tahun 1991 tidak dilakukan hanya atas dasar iniasi dari kalangan pemerintah saja, jauh sebelum itu pembahasan mengenai keinginan untuk diadakan sebuah pertemuan kebudayaan tingkat nasional yang membahas mengenai perkembangan kebudayaan Indonesia telah dibicarakan, namun memang respon dan tindakannya belum ada.

Pelaksanaan Kongres Kebudayaan tahun 1991 didasari oleh Ketetapan MPR No. II/MPR/1988, yang menggarisbawahi bahwa pembangunan nasional adalah pembangunan berbudaya. Tetapi, hal ini pun kontradiktif sebab dalam Ketetapan MPR No. II/MPR/1988 mengenai GBHN, dijelaskan dibagian Arah Pembangunan Jangka Panjang, bahwa Sasaran Utama Pembangunan Jangka Panjang adalah terciptanya landasan yang kuat bagi bangsa Indonesia untuk tumbuh dan berkembang atas kekuatannya sendiri menuju masyarakat yang adil dan makmur berdasarkan Pancasila.

Fakta sejarah lain yang memiliki hubungan dalam pelaksanaan Kongres Kebudayaan tahun 1991, terjadi juga ditahun 1988, tepat pada saat didelakrasikan The World Decade for Cultural Development 1988 - 1997. Dalam sebuah catatan mengenai awalnya terbentuk gagasan The World Decade for Cultural Development (Dasawarsa Dunia untuk Pengembangan Kebudayaan), dijelaskan sebagai berikut;

"Acting on proposals by the Member States which took part in the World Conference on Cultural Policies in Mexico City, the United Nations General Assembly approved the proclamation of a 'World Decade for Cultural Development' as a period for self-analysis during which countries would engage in a process of reflection, adopt policies and undertake activities designed to ensure the integrated development of their societies. The Decade began in 1988 and ended in 1997." (Maria Paola, 1988: 5).

Sebagai upaya dalam mensukseskan pembangunan berkelanjutan dengan tidak hanya memperhatikan pembangunan dalam pendekatan ekonomi, PBB melalui UNESCO akhirnya 
memaksa seluruh negara yang tergabung didalamnya untuk memaksimalkan segala potensi yang ada di masyarakat masing-masing negara agar mampu menciptakan kondisi yang meningkatkan kualitas hidup dan kesejahteraan material dan spritual manusia.

Secara garis besar, deklarasi ini menjadi tuntutan untuk berbagai negara yang tergabung dalam PBB (Perserikatan Bangsa-Bangsa) untuk melaksanakan agenda kebudayaan nasional dengan menyesuaikan kebutuhan dan kondisi masyarakatnya serta melakukan refleksi dan adopsi atas kebijakan kebudayaan internasional. Untuk mensukseskan program tersebut Indonesia melaksanakan berbagai kegiatan antara lain: Kongres Kebudayaan 1991, Seminar Silk Road (Jalur Sutra) di Surabaya tahun 1993, Seminar Budaya dan Budidaya Kesenian di Sumatra Barat, dll (Nunus Supardi, 2016: 195). Fakta ini semakin mengarahkan pada kenyataan bahwa Kongres Kebudayaan tahun 1991 dilakukan sebagai "program" atau "kegiatan” belaka yang memang diadakan untuk kepentingan dari pemerintahan Orde Baru.

Inilah yang menjadi keunikan dalam Kongres Kebudayaan tahun 1991, sedari awal pelaksanaannya memang diperuntukkan untuk berbagai kepentingan pemerintahan. Dengan demikian sepertinya terlalu menyederhanakan konteks sosial politik bilamana hanya melihat Kongres Kebudayaan tahun 1991 didorong dari tuntutan dan keinginan masyarakat dalam pengertian seniman dan budayawan saat itu.

\section{Skema 1}

\section{Latar Belakang Pelaksanaan Kongres Kebudayaan Indonesia Tahun 1991}

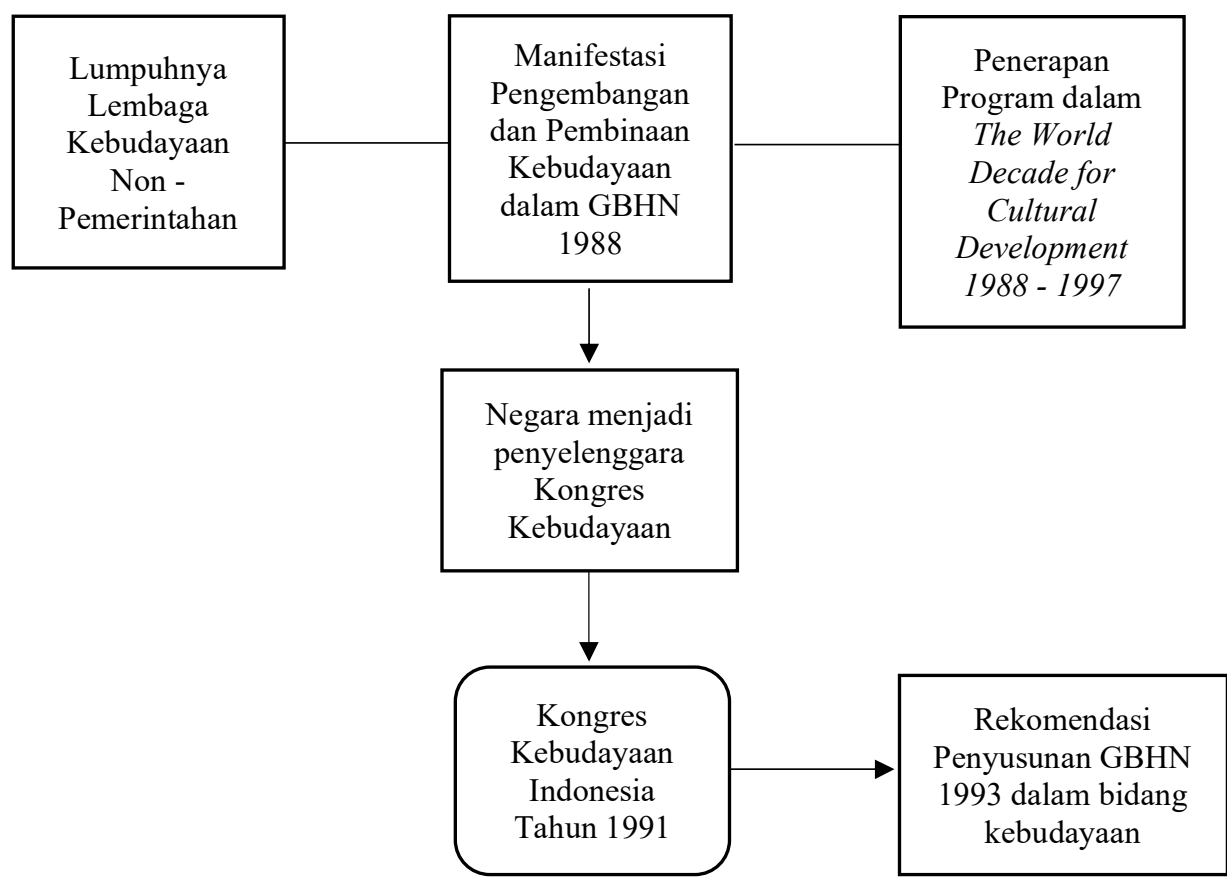


Kongres Kebudayaan tahun 1991 merepsentasikan model budaya komando khas Orde Baru dengan upaya menonjolkan peranannya melalui perubahan mekanisme kongres yang menjadi terpusat di lembaga kebudayaan pemerintahan dan fokus grand design pemerintahannya. Inilah yang perlu dikritisi, bahwa perubahan-perubahan dalam pelaksanaan kongres dengan mengadakan "pra kongres kebudayaan" sebagai hasil dari "penjaringan” datadata terkait perkembangan kebudayaan didaerah-daerah yang memberikan kesan objektif dan transparan, tidak lebih dari upaya untuk memperluas intervensi negara terkait aspek kebudayaan dalam masyarakat dan menjadi pertimbangan dalam arah pembangunan nasional yang diinginkan rezim.

\section{Gambar 2}

Prof. Dr. S. Boedisantoso (Ketua Panitia Penyelenggara) sedang memandu sidang Kongres Kebudayaan tanggal 28 Oktober s.d. 3 November 1991 di Taman Mini Indonesia Indah, Jakarta.

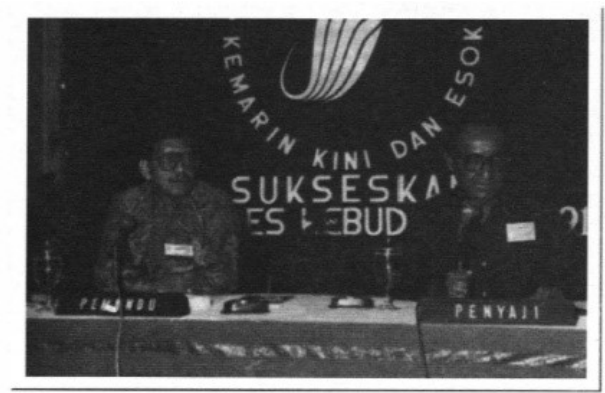

Sumber: Nunus Supardi, 2013.

Dapat disimpulkan bahwa keterlibatan negara dalam setiap kegiatan atau tradisi yang berkembang dalam masyarakat membuka ruang untuk kritik atas setiap kebijakan dan strategi kebudayaan yang diterapkan dan merumuskan diskurus kebudayaan yang sesuai. Untuk melakukan tinjauan lebih mendalam akan dijelaskan mengenai gagasan yang berkembang dalam Kongres Kebudayaan tahun 1991 dari pandangan para tokoh penyampai makalah kebudayaan dan kontestasi gagasan didalamnya terkait perkembangan kebudayaan yang berhubungan dengan kebutuhan politik kebudayaan nasional dibagian selanjutnya.

\section{Profil Pemakalah dalam Kongres Kebudayaan Indonesia Tahun 1991}

Untuk melihat posisi pemakalah didalam Kongres Kebudayaan Indonesia Tahun 1991, pada bagian ini akan diuraikan secara singkat biografi pemakalah. Hal ini dilakukan untuk melihat hubungan pemakalah yang berada didalam struktur kekuasaan dan pemakalah yang tidak terlibat didalamnya. Secara konsekuen, struktur berpikir dan logika yang digunakan oleh pemakalah dalam penyampaian gagasannya akan terlihat berbeda terkait persoalan 
kebudayaan. Untuk lebih jelasnya, peneliti akan menguraikannya dalam bentuk tabel sebagai berikut;

Tabel 1

Tabel Profil Pemakalah dalam Kongres Kebudayaan Indonesia Tahun 1991

\begin{tabular}{|c|c|c|c|c|}
\hline No & Nama & Profesi & $\begin{array}{c}\text { Latar Belakang } \\
\text { Pendidikan }\end{array}$ & Karya-Karya \\
\hline 1 & $\begin{array}{l}\text { Sutan Takdir Alihsjahbana } \\
\text { (11 Februari } 1908 \text { - } 17 \text { Juli } \\
\text { 1994) }\end{array}$ & Budayawan & $\begin{array}{l}\text { HIS (Bengkulu), } \\
\text { Kweekschool } \\
\text { (Bukittinggi), HKS } \\
\text { (Bandung), Sekolah } \\
\text { Tinggi di Jakarta, Honoris } \\
\text { Causa di Universitas } \\
\text { Indonesia, dan Universitas } \\
\text { Sains, Malaysia, Penang. }\end{array}$ & $\begin{array}{l}\text { Polemik Kebudayaan (Balai } \\
\text { Pustaka, Edisi III, 1977) dan } \\
\text { Perkembangan Sejarah } \\
\text { Kebudayaan Dilihat dari } \\
\text { Jurusan Nilai-Nilai (Idayu, } \\
\text { Edisi II, 1977). } \\
\text { (https://ensiklopedia.kemdikb } \\
\text { ud.go.id/sastra/artikel/Sutan } \\
\text { Takdir_Alisjahbana, akses } \\
\text { tanggal 18 Februari 2021). }\end{array}$ \\
\hline 2 & $\begin{array}{l}\text { Nirwan Dewanto } \\
\text { (28 September 1961) }\end{array}$ & $\begin{array}{l}\text { Budayawan, } \\
\text { Kurartor, } \\
\text { dan Aktor. }\end{array}$ & $\begin{array}{l}\text { Jurusan Geologi, Fakultas } \\
\text { Teknologi Mineral, ITB } \\
\text { tahun } 1980 .\end{array}$ & $\begin{array}{l}\text { Puisi, Antologi Jantung Lebah } \\
\text { Ratu (2007), Esai, Senjakala } \\
\text { Kebudayaan (1996), Jurnal } \\
\text { Kebudayaan Kalam, Film, } \\
\text { Soegija (2012) } \\
\text { (https://www.kapanlagi.com/n } \\
\text { irwan-dewanto/profil/, akses } \\
\text { tanggal } 18 \text { Februari 2021) }\end{array}$ \\
\hline 3 & $\begin{array}{l}\text { Barnabas Suebu } \\
\text { (29 April 1946) }\end{array}$ & $\begin{array}{l}\text { Gubernur } \\
\text { Irian Jaya } \\
(1988-1993)\end{array}$ & $\begin{array}{l}\text { Fakultas Hukum, } \\
\text { Universitas Cendrawasih } \\
\text { (1976) dan Kursus } \\
\text { Reguler Angkatan XVII } \\
\text { Lemhanas (1984) } \\
\text { (https://www.papua.go.id/ } \\
\text { view-detail-tokoh- } \\
\text { 12/undefined, akses } \\
\text { tanggal 18 Februari 2021). }\end{array}$ & - \\
\hline 4 & $\begin{array}{l}\text { Umar Kayam } \\
\text { (30 April } 1932 \text { - } 16 \text { Maret } \\
\text { 2002) }\end{array}$ & Budayawan & $\begin{array}{l}\text { Fakultas Pedagogik, } \\
\text { Universitas Gadjah Mada } \\
\text { pada tahun (1955) dan } \\
\text { Universitas New York } \\
\text { (1963), dan Ph.D. dari } \\
\text { Universitas Cornell } \\
\text { (1965). }\end{array}$ & $\begin{array}{l}\text { Esai Kebudayaan Seni, } \\
\text { Tradisi, dan Masyarakat } \\
\text { (1981) dan Sejumlah Masalah } \\
\text { Sastra (1983) } \\
\text { (http://ensiklopedia.kemdikbu } \\
\text { d.go.id/sastra/artikel/Umar_K } \\
\text { ayam, akses tanggal 18 } \\
\text { Februari 2021). }\end{array}$ \\
\hline 5 & Wayan Geriya & Antropolog & $\begin{array}{l}\text { Jurusan Antropologi, } \\
\text { Fakultas Sastra, } \\
\text { Universitas Udayana }\end{array}$ & $\begin{array}{l}\text { Strategi dan Implementasi } \\
\text { Undang-Undang Pemajuan } \\
\text { Kebudayaan di Bali } \\
\text { (https://kebudayaan.kemdikbu } \\
\text { d.go.id/bpnbbali/wayan- } \\
\text { geriya-strategi-dan- } \\
\text { implementasi-undang- } \\
\text { undang-pemajuan- } \\
\text { kebudayaan-di-bali/, akses } \\
\text { tanggal } 18 \text { Februari 2021). }\end{array}$ \\
\hline 6 & $\begin{array}{l}\text { H.A.R Tilaar } \\
\text { (16 Juni } 1932-30 \text { Oktober } \\
\text { 2019) }\end{array}$ & $\begin{array}{l}\text { Dosen dan } \\
\text { Guru Besar } \\
\text { Emeritus } \\
\text { Universitas } \\
\text { Negeri }\end{array}$ & $\begin{array}{l}\text { Louwerier School } \\
\text { (Sekolah Rakyat) (1946), } \\
\text { Chr. Normaal School, } \\
\text { Tomohon (1950). } \\
\text { Kweekschool, Tomohon, } \\
\text { (1952). Sekolah }\end{array}$ & $\begin{array}{l}\text { Pendidikan dalam } \\
\text { Pembangunan Nasional } \\
\text { Menyongsong Abad XXI, } \\
\text { Balai Pustaka (1990). } \\
\text { Manifesto Pendidikan } \\
\text { Nasional: Tinjauan dari }\end{array}$ \\
\hline
\end{tabular}




\begin{tabular}{|c|c|c|c|c|}
\hline & & $\begin{array}{l}\text { Jakarta } \\
\text { (UNJ). }\end{array}$ & $\begin{array}{l}\text { Pendidikan Guru B-I dan } \\
\text { B-II Ilmu Mendidik, } \\
\text { Bandung (1957-1959). } \\
\text { Universitas Indonesia } \\
\text { (1961). }\end{array}$ & $\begin{array}{l}\text { Perspektif Postmodernisme } \\
\text { dan Studi Kultural (2005) } \\
\text { (https://indonesiatera.com/pro } \\
\text { f-dr-har-tilaar-msced/, pada } \\
\text { tanggal } 18 \text { Februari 2021). }\end{array}$ \\
\hline 7 & $\begin{array}{l}\text { Arief Budiman } \\
\text { (3 Januari } 1941-23 \text { April } \\
\text { 2020) }\end{array}$ & $\begin{array}{l}\text { Aktivis, } \\
\text { Dosen, } \\
\text { redaktur } \\
\text { majalah, } \\
\text { anggota } \\
\text { DKJ dan } \\
\text { Badan } \\
\text { Sensor Film. }\end{array}$ & $\begin{array}{l}\text { Ilmu Pendidikan, College } \\
\text { d'Europe, Brugge, Belgia } \\
\text { (1964). Fakultas } \\
\text { Psikologi, Universitas } \\
\text { Indonesia (1968), Paris } \\
\text { (1972), dan Sosiologi, } \\
\text { Universitas Harvard, } \\
\text { Amerika Serikat (1980). }\end{array}$ & $\begin{array}{l}\text { Pembagian Kerja Secara } \\
\text { Seksual: Sebuah Pembahasan } \\
\text { Sosiologis Tentang Peran } \\
\text { Wanita Di Dalam Masyarakat } \\
\text { (Gramedia, 1982). } \\
\text { (https://www.suara.com/news } \\
\text { /2020/09/18/184402/profil- } \\
\text { arief-budiman-ketua-kpu-ri- } \\
\text { dari-pendidikan-hingga- } \\
\text { karier, akses tanggal } 18 \\
\text { Februari 2018). }\end{array}$ \\
\hline 8 & $\begin{array}{l}\text { M. Dawam Rahardjo } \\
\text { (20 April } 1942-30 \text { Mei } \\
\text { 2018) }\end{array}$ & $\begin{array}{l}\text { Ekonom dan } \\
\text { Budayawan }\end{array}$ & $\begin{array}{l}\text { Borach High School, } \\
\text { Idaho, Amerika Serikat } \\
\text { (1961), Fakultas Ekonomi } \\
\text { Universitas Gadjah Mada } \\
\text { (1969) }\end{array}$ & $\begin{array}{l}\text { Esai-Esai Ekonomi Politik } \\
\text { (1983), Deklarasi Mekah: } \\
\text { Esai-Esai Ekonomi Islam } \\
\text { (1987), Ekonomi Politik dan } \\
\text { Pembangunan (2014). } \\
\text { (https://www.merdeka.com/da } \\
\text { wam-rahardjo/profil/, akses } \\
\text { tanggal } 18 \text { Februari 2021). }\end{array}$ \\
\hline 9 & $\begin{array}{l}\text { W.S. Rendra } \\
\text { (7 November } 1935 \text { - } 6 \\
\text { Agustus 2009) }\end{array}$ & Budayawan & $\begin{array}{l}\text { Jurusan Sastra Inggris, } \\
\text { Fakultas Sastra dan } \\
\text { Kebudayaan, Universitas } \\
\text { Gajah Mada, Yogyakarta, } \\
\text { American Academy of } \\
\text { Dramatical Art (1954) }\end{array}$ & $\begin{array}{l}\text { Orang-orang di Tikungan } \\
\text { Jalan (1954), Bib Bob } \\
\text { Rambate Rate Rata (Teater } \\
\text { Mini Kata) (1967). } \\
\text { (https://www.biografiku.com/ } \\
\text { biografi-ws-rendra/, akses } \\
\text { tanggal } 18 \text { Februari 2021). }\end{array}$ \\
\hline 10 & $\begin{array}{l}\text { Soemitro } \\
\text { (29 Mei } 1917 \text { - } 9 \text { Maret } \\
\text { 2001) }\end{array}$ & Ekonom & $\begin{array}{l}\text { Bachelor of Arts }(B A), \\
\text { Netherlands School of } \\
\text { Economics, Universitas } \\
\text { Sorbonne, Paris. }\end{array}$ & $\begin{array}{l}\text { Jejak Perlawanan Begawan } \\
\text { Pejuang, Pustaka Sinar } \\
\text { Harapan, (2000). } \\
\text { (https://initu.id/biografi- } \\
\text { soemitro-djojohadikoesoemo- } \\
\text { begawan-ekonomi-indonesia/, } \\
\text { akses tanggal } 18 \text { Februari } \\
\text { 2021). }\end{array}$ \\
\hline 11 & $\begin{array}{l}\text { Y.B. Mangunwijaya } \\
\text { (6 Mei } 1929-10 \text { Februari } \\
\text { 1999) }\end{array}$ & Arsitek & $\begin{array}{l}\text { Institut Filsafat dan } \\
\text { Teologi Sancti Pauli, } \\
\text { Yogyakarta (1959), } \\
\text { Sekolah Teknik Tinggi di } \\
\text { Rhein, Westfalen, Aachen, } \\
\text { Republik Federal Jerman } \\
\text { (1966). }\end{array}$ & $\begin{array}{l}\text { Renungan Fenomenologis } \\
\text { Religius Kehidupan Sehari- } \\
\text { Hari (1975) Puntung-Puntung } \\
\text { Roro Mendut, kumpulan esai } \\
\text { dalam Harian Kompas } \\
\text { 1973_1977 (1978). } \\
\text { (http://ensiklopedia.kemdikbu } \\
\text { d.go.id/sastra/artikel/Y_B_Ma } \\
\text { ngunwijaya, akses tanggal } 18 \\
\text { Februari 2021). }\end{array}$ \\
\hline
\end{tabular}

Sumber: ensiklopedia.kemendikbud.com, biografiku.com, kapanlagi.com, merdeka.com, 2021.

Tabel diatas menunjukkan bahwa tokoh-tokoh yang menjadi penyampai makalah kebudayaan kebanyakan berasal dari kalangan budayawan dan ekonom. Dari karya-karya yang dihasilkan oleh pemakalah diatas hampir seluruhnya pernah menulis dan berkegiatan dibidang kebudayaan. Selain itu, pemakalah diatas juga mengalami dan merasakan proses transisi dari pemerintahan Orde Lama ke Orde Baru yang dilihat berdasarkan riwayat hidupnya. Pemaparan 
singkat terkait profil pemakalah menjadi pengantar untuk memahami gagasan yang disampaikannya dalam kongres. Karya-karya kebudayaan dan akademik yang dibuat oleh setiap pemakalah secara tidak langsung berkaitan dengan keilmuan dan pengetahuan yang dimilikinya dan juga menjadi fokus pembahasan dalam makalah kebudayaannya.

\section{Sebelas Teks Makalah Kebudayaan dalam Kongres Kebudayaan Indonesia Tahun 1991}

Untuk mempermudah dalam menguraikan kesebelas teks, peneliti akan mengkategorisasikan teks kedalam beberapa konsep kunci. Pertama, kebudayaan sebagai nilai, kedua, kebudayaan sebagai kebijakan, ketiga, kebudayaan sebagai bahasa atau pemahaman, keempat, kebudayaan sebagai kesatuan, dan kelima, kebudayaan sebagai standarisasi. Sebelas teks tersebut diambil dari lima jilid bunga rampai sub-tema pembahasan kongres yang menghimpun keseluruhan teks dari pemakalah sebagai berikut, tema pembahasan mengenai Warisan Budaya: Penyaringan dan Pemeliharaan (Buku I) disampaikan sebanyak dua puluh empat makalah. Pembahasan Kebudayaan Nasional: Kini dan Dimasa Depan (Buku II) disampaikan sebanyak dua puluh tiga makalah, pembahasan Daya Cipta dan Perkembangan Kebudayaan (Buku III) disampaikan sebanyak lima belas makalah, tema pembahasan mengenai Kebudayaan dan Sektor-Sektor Kehidupan Masyarakat (Buku IV) disampaikan sebanyak tiga belas makalah, dan dalam tema bahasan Kebudayaan Indonesia dan Dunia (Umat Manusia) (Buku V) disampaikan sebanyak empat belas makalah.

Sebelas makalah kebudayaan yang disampaikan para tokoh dalam Kongres Kebudayaan Tahun 1991 juga akan di analisis atas struktur teks tersebut. Analisis struktur teks dijelaskan melalui Cultural Analysis of Text (analisis kebudayaan dalam teks) dan hermeneutika menurut Paul Riceour. Dalam perspektif cultural studies, Hal tersebut dijelaskan oleh Douglas Kellner seperti dalam kutipan berikut;

"To avoid the critique of textualism, of severing the political and ideological dimensions of the phenomena studied, one needs to approach it from multiple perspectives and to deploy a wide range of methods. Douglas Kellner has frequently suggested for cultural studies to develop a "multiperspectival approach" which includes investigation of a wide range of artefacts interrogating relationships within the three dimensions of 1) the production and political economy of culture; 2) textual analysis and critique of its artefacts; and 3) study of audience reception and the uses of me-dia/cultural products" (Urpa Kolova, 2002: 5).

Dalam melakukan perbandingan atas teks dan terlebih melakukan rekonstruksi ataupun dekonstruksi, semua harus didasari pada kualifikasi tertentu yang dapat memberikan gambaran terkait pesan, makna, dan ideologi yang terdapat didalamnya. Mikko Lehtonen dalam bukunya The Cultural Analysis of Text (2000) mengembangkan suatu model analisis teks untuk memahami kajian makna dan interpretasi dalam perspektif cultural studies. Ketiga model analisis tersebut berpijak pada teks itu sendiri, konteks, dan pembaca. Ia menguraikan bahwa 
pada dasarnya untuk memahami suatu teks yang pertama harus dilakukan adalah mendekonstruksi isi teks yang bertujuan untuk menggali setiap pesan, wacana, dan ideologi yang ada didalamnya, selanjutnya adalah melakukan rekonstruksi dari teks dan melihat kepada konteks, hal ini berkaitan dengan relasi teks dengan situasi kultural, sosial, dan politik dari struktur masyarakat, dan yang terakhir adalah membentuk suatu interpretasi dan makna, untuk ini posisi setiap pembaca dalam memahami isi teks menjadi penting (Mikko Lehtonen, 2000: 56). Sebelas makalah kebudayaan tersebut akan dijelaskan berdasarkan konsep tersebut, untuk bisa membandingkan isi dan pesan yang disampaikan berkaitan dengan tujuan juga kepentingan yang ada didalamnya.

\section{Konstruksi Diskursus Budaya Orde Baru pada Lima Makalah Kebudayaan dalam Kongres Kebudayaan Indonesia Tahun 1991}

Orde Baru memanfaatkan segala bentuk kekuatan politik bahkan institusi sosial di masyarakat dalam me-rekonstruksi ide-ide dominan yang dirancangnya untuk kepentingan politik dan ekonominya. Manifestasinya tidak terbatas pada level praktik melalui kebijakan dan strategi kebudayaan saja, tetapi pada konteks tertentu, pemerintahan Orde Baru juga melakukan hegemoni atas kesadaran dan struktur logika masyarakat melalui gagasan-gagasan yang selaras dengan kepentingannya. Pada bagian ini, peneliti akan menguraikan beberapa gagasan terkait persoalan budaya yang disampaikan pada Kongres Kebudayaan Indonesia Tahun 1991 yang mendukung konsepsi pembangunan nasional dan kebudayaan nasional, sebagai berikut;

1. Sejarah Kebudayaan Indonesia Masuk Globalisasi Umat Manusia (Departemen Pendidikan dan Kebudayaan, Direktorat Jenderal Kebudayaan' Buku V, ${ }^{1992: 269)}$ oleh Sutan Takdir Alisjahbana, termasuk dalam kebudayan sebagai nilai. Terkait pembangunan nasional, menurutnya, untuk mengejar keterbelakangan itu, kita mesti banyak mengeluarkan belanja untuk pendidikan (Departemen Pendidikan dan Kebudayaan, Direktorat Jenderal Kebudayaan' Buku V, 1992: 283). Sedangkan dalam modernisasi kebudayaan Indonesia, Ia menjelaskan bahwa kemajuan kebudayaan modern tak dapat lagi ditahan nafsunya untuk mengetahui dan menguasai kebudayaan modern yang didukung ilmu, teknologi, dan ekonomi itu. (Departemen Pendidikan dan Kebudayaan, Direktorat Jenderal Kebudayaan'Buku V, 1992: 280).

2. Kontak-Kontak Budaya dalam Pembinaan dan Pengembangan Budaya Bangsa oleh Barbanas Suebu (Departemen Pendidikan dan Kebudayaan, Direktorat Jenderal Kebudayaan' Buku II: 1992), termasuk dalam kebudayaan sebagai standarisasi. Terkait pembangunan nasional, menurutnya, Pembangunan nasional sebagai 
pembangunan berbudaya didasarkan pada nilai-nilai luhur bangsa dan sikap budaya yang mampu menjawab tantangan-tantangan pembangunan (Departemen Pendidikan dan Kebudayaan, Direktorat Jenderal Kebudayaan’ Buku II, 1992: 23). Modernisasi kebudayaan Indonesia dijelaskan dalam pengembangan budaya yang didasarkan pada pola keterikatan antara kebudayaan, struktur sosial dan Bahasa. (Departemen Pendidikan dan Kebudayaan, Direktorat Jenderal Kebudayaan' Buku II, 1992:25).

3. Keserasian Pengembangan Kebudayaan Daerah dan Kebudayaan Nasional dalam Pembangunan Jangka Panjang Tahap II 1994-2019 (Departemen Pendidikan dan Kebudayaan, Direktorat Jenderal Kebudayaan' Buku I: 1992) oleh Wayan Geriya, termasuk dalam kebudayaan sebagai kebijakan. Pendapatnya terkait pembangunan nasional adalah arah pengembangan kebudayaan harus serasi dengan arah dan tujuan pembangunan nasional (Departemen Pendidikan dan Kebudayaan, Direktorat Jenderal Kebudayaan' Buku I, 1992: 504). Sedangkan terkait modenisasi kebudayaan, menurutnya, iptek dan nilai ekonomi merupakan dua perangkat nilai yang dominan dalam sistem budaya global (Departemen Pendidikan dan Kebudayaan, Direktorat Jenderal Kebudayaan’ Buku I, 1992: 498).

4. Budaya Nasional dan Budaya Daerah (Departemen Pendidikan dan Kebudayaan, Direktorat Jenderal Kebudayaan' Buku I: 1992), oleh Soemitro, termasuk dalam kebudayaan sebagai standarisasi. Menurutnya, pembangunan nasional adalah menyempurnakan dan memfinalkan proses "nation \& character building”, maka diambillah unsur positif dari semua sumber inspirasi dan ditiadakan unsur negatifnya (Departemen Pendidikan dan Kebudayaan, Direktorat Jenderal Kebudayaan' Buku I, 1992: 394). Untuk mencapai modernisasi kebudayaan, Ia menyampaikan bahwa demokrasi berkembang subur dan dapat menjamin kelangsungan ekonomi nasional. Esensi dari demokrasi politik dan ekonomi adalah liberalisme, kebebasan, dan persaingan. Jiwa persaingan adalah tuntutan masa depan interaksi ekonomi dan budaya secara global. (Departemen Pendidikan dan Kebudayaan, Direktorat Jenderal Kebudayaan’ Buku I, 1992: 401-402).

5. Pendidikan dan Kebudayaan Nasional: Fungsi dan Peranan SISDIKNAS dalam Pembangunan yang Berbudaya (Departemen Pendidikan dan Kebudayaan, Direktorat Jenderal Kebudayaan' Buku II: 1992) oleh H.A.R. Tilaar, termasuk dalam kebudayaan sebagai kebijakan. Menurutnya, dalam pembangunan nasional SISDIKNAS dengan segala perangkatnya dapat berfungsi atau difungsikan ke arah pengembangan budaya nasional (Departemen Pendidikan dan Kebudayaan, Direktorat Jenderal Kebudayaan' 
Buku II, 1992: 429-430). Untuk menuju modernisasi kebudayaan Indonesia, Ia menjelaskan bahwa pendidikan dalam kehidupan yang memberikan nilai yang tinggi terhadap nilai kebebasan dan kreativitas akan menempatkan nilai keunggulan sebagai pengarah dalam proses belajar mengajar. Nilai keunggulan ini akan merangsang peningkatan produktivitas dan kualitas, displin dalam berpikir, dan disiplin dalam bekerja (Departemen Pendidikan dan Kebudayaan, Direktorat Jenderal Kebudayaan' Buku II, 1992: 430).

Berdasarkan makalah kebudayaan yang disampaikan oleh kelima tokoh tersebut memandang perkembangan dan kemajuan dalam kehidupan bermasyarakat dapat dimungkinkan dengan menyesuaikan dan mengikuti segala bentuk kebijakan dan strategi kebudayaan pemerintahan Orde Baru. Selain itu, kelima tokoh tersebut juga menganggap bahwa permasalahan dan upaya merumuskan kebudayaan adalah bagian dari upaya mendukung kemajuan ekonomi. Kebudayaan daerah dari pandangan kelima tokoh diatas adalah menempatkannya sebagai pendukung kebudayaan nasional dan pembangunan nasional. Dari pembedahan terhadap teks yang dilakukan oleh peneliti, tidak ditemukan adanya argumentasi atau pendapat yang berangkat dari kondisi rill yang dirasakan oleh masyarakat terkait kebijakan dan strategi budaya pemerintahan Orde Baru.

\section{Dekonstruksi Diskursus Budaya Orde Baru pada Enam Makalah Kebudayaan dalam}

\section{Kongres Kebudayaan Indonesia Tahun 1991}

Dibagian ini akan diuraikan pandangan lain terkait persoalan budaya yang disampaikan oleh para pemakalah dalam Kongres Kebudayaan Indonesia Tahun 1991, khususnya pandangan yang melihat dampak-dampak dari praktik yang dilakukan Orde Baru terkait kebijakan dan strategi kebudayaannya. Ada enam teks yang akan diuraikan pada bagian ini, keenam teks tersebut disampaikan oleh tokoh yang memang memiliki konsentrasi pada isu-isu kebudayaan dan aktif berkegiatan di bidang kebudayaan. Keenam tokoh ini memiliki cara pandang lain terkait kebudayaan yang lebih fokus kepada hubungan negara dan struktur masyarakat termasuk gagasan ideal yang seharusnya dipikirkan terkait persoalan kebudayaan. Lebih jelasnya akan diuraikan sebagai berikut;

1. Kebudayaan Indonesia: Pandangan Seorang Penyair (Departemen Pendidikan dan Kebudayaan, Direktorat Jenderal Kebudayaan, Buku V, 1992: 199) oleh Nirwan Dewanto, termasuk dalam kebudayaan sebagai bahasa. Pembangunan nasional, menurutnya, adalah bagaimana kebudayaan Indonesia berevolusi melalui satuan-satuan kecil, satuan-satuan mikroskopik sekalipun. Hasil evolusi itu adalah bukti dari daya hidup kebudayaan kita sekaligus bukti makin tak terhindarnya pengaruh kekuatan modial. 
(Departemen Pendidikan dan Kebudayaan, Direktorat Jenderal Kebudayaan, Buku V, 1992: 208). Sedangkan dalam modernisasi kebudayaan Indonesia, Ia menyampaikan bahwa kita terjebak dalam mencari totalitas, tetapi tidak ada jalan tunggal menuju kesana. Oleh karena itu saya tidak menganjurkan untuk membuat desain besar tentang kebudayaan nasional Indonesia (Departemen Pendidikan dan Kebudayaan, Direktorat Jenderal Kebudayaan, Buku V, 1992: 212 \& 219).

2. Kebudayaan Nasional, Kebudayaan Baru (Departemen Pendidikan dan Kebudayaan, Direktorat Jenderal Kebudayaan, Buku II, 1992: 433) oleh Umar Kayam, termasuk dalam kebudayaan sebagai nilai. Terkait pembangunan nasional, Ia menyampaikan bahwa seharusnya dilakukan dengan membangun dan mengembangkan suatu sistem politik yang demokratis, menciptakan sistem ekonomi yang adil dan mampu bersaing. Suatu sistem pendidikan yang mendorong perkembangan ilmu pengetahuan dan teknologi. Mengembangkan suatu sistem kesenian yang kaya serta penuh vitalitas (Departemen Pendidikan dan Kebudayaan, Direktorat Jenderal Kebudayaan, Buku II, 1992: 460). Sedangkan dalam mencapai modernisasi kebudayaan, menurutnya dengan bergerak dan mengerahkan semua modal-modal budaya, semua jenius lokal kita yang terpendam diseantero kepulauan kita dari Sabang sampai Marauke dan Timor Dili, untuk membuat modernitas yang tidak sepi, tidak sinis, tidak dingin tetapi pebuh gairah, kreatif dan demokratis (Departemen Pendidikan dan Kebudayaan, Direktorat Jenderal Kebudayaan, Buku II, 1992: 452).

3. Daya Cipta Ilmu dan Teknologi Dalam Pertumbuhan Indonesia (Departemen Pendidikan dan Kebudayaan, Direktorat Jenderal Kebudayaan, Buku III, 1992: 261) oleh Y.B. Mangunwijaya, termasuk dalam kebudayaan sebagai bahasa. Untuk pembangunan nasional, menurutnya, demikianlah jika kita ingin menjadi bangsa yang maju dan kuat bertahan, maka perlulah konsekuen dan konsisten memahami iklim dan tanah - tumbuh yang diperlukan agar sains dan teknologi dapat bertumbuh pesat, subur, dan berbuah secara wajar alami, bahkan dipupuk pengembangannya (Departemen Pendidikan dan Kebudayaan, Direktorat Jenderal Kebudayaan, Buku III, 1992: 264). Sedangkan dalam modernisasi kebudayaan, menurutnya, melalui dua sikap dan perangai dasar diperlukan demi ketahanan dan pengembangan bangsa maupun pribadi manusia. Tidak terkecuali bangsa Indonesia, yakni jiwa eksploratif yang selalu mencari dan bertanya juga menelusur melampaui batas - batas kesempitan diri, yaitu jiwa kreatif (Departemen Pendidikan dan Kebudayaan, Direktorat Jenderal Kebudayaan, Buku III, 1992: 261). 
4. Renungan Dasar Tentang Kebudayaan (Departemen Pendidikan dan Kebudayaan, Direktorat Jenderal Kebudayaan, Buku II, 1992: 353) oleh W.S. Rendra, termasuk dalam kebudayaan sebagai bahasa. Pandangannya terkait pembangunan nasional adalah Keadaan politik kita saat ini sudah jauh dari daulat rakyat. Oleh karena itu kesehatan kehidupan politik perlu dipulihkan. Adapun hal kedua yang perlu dilakukan didalam menyehatkan kehidupan politik adalah sentralisasi kekuasaan. Sebab sentralisasi kekuasaan ternyata melahirkan kurang meratanya hak-hak rakyat dibidang politik, hukum, ekonomi, sosial, dan budaya (Departemen Pendidikan dan Kebudayaan, Direktorat Jenderal Kebudayaan, Buku II, 1992: 364 - 366). Terkait modernisasi kebudayaan dapat dilakukan dengan menanggulangi krisis budaya tersebut agen reformasi budaya yang terpenting adalah pendidikan. Melewati pendidikan harus lebih ditekankan laku pengumpulan fakta dan analisis terhadap fakta sebagai dasar untuk berpikir objektif, yang selanjutnya disempurnakan dengan laku verifikasi (Departemen Pendidikan dan Kebudayaan, Direktorat Jenderal Kebudayaan, Buku II, 1992: 363).

5. Arah Perkembangan Kebudayaan Nasional Kita dan Dunia: Mencoba Mencari Alternatif Terhadap Sistem Kapitalisme (Departemen Pendidikan dan Kebudayaan, Direktorat Jenderal Kebudayaan, Buku V, 1992: 19) oleh Arief Budiman, termasuk dalam kebudayaan sebagai kesatuan. Terkait pembangunan nasional adalah tanah mereka dirampas demi pembangunan, pekerjaan mereka dihancurkan demi keindahan kota dan pariwisata. Kepentingan kaum borjuis, dalam bentuk perolehan fasilitas-fasilitas untuk mendirikan pabrik-pabrik dan usaha-usaha lainnya yang pada dasarnya menguntungkan kaum ini, dinyatakan sebagai kepentingan nasional (Departemen Pendidikan dan Kebudayaan, Direktorat Jenderal Kebudayaan, Buku V, 1992: 32-33). Untuk modernisasi kebudayan, baginya tumbuhnya kapitalisme ini juga mempengaruhi perkembangan kesenian di Indonesia. Bentuk seni yang paling berkembang sekarang adalah musik pop, karena musik inilah yang digandrungi oleh masyarakat kelas menengah ke atas Indonesia (Departemen Pendidikan dan Kebudayaan, Direktorat Jenderal Kebudayaan, Buku V, 1992: 25).

6. Kebudayaan dan Ekonomi (Departemen Pendidikan dan Kebudayaan, Direktorat Jenderal Kebudayaan, Buku IV, 1992: 39) oleh M. Dawam Rahardjo, termasuk dalam kebudayaan sebagai kesatuan. Pembangunan nasional menurutnya berkaitan terbentuknya rezim politik yang kuat, sebagai dukungan terhadap rencana pembangunan jangka Panjang yang perlu dilaksanakan secara konsisten dan 
berkesinambungan, menghasilkan kebijaksanaan stabilitas politik dan ekonomi, yang dalam konsep Trilogi Pembangunan. Ini saja sudah cukup dijadikan indikator, bahwa politik tetap menjadi panglima (Departemen Pendidikan dan Kebudayaan, Direktorat Jenderal Kebudayaan, Buku IV, 1992: 50). Sedangkan modernisasi kebudayaan adalah masuknya teknologi, yang sebagian untuk keperluan produksi dan sebagai alat-alat konsumsi itu menimbulkan keharusan penyesuaian dari masyarakat. Mereka itu memasuki cara hidup baru, yaitu cara hidup yang mengikuti cara bekerjanya teknologi dalam menghasilkan barang-barang (Departemen Pendidikan dan Kebudayaan, Direktorat Jenderal Kebudayaan, Buku IV, 1992: 61).

Keenam teks tersebut memiliki kesamaan perihal alternatif untuk mengatasi permasalahan budaya, yaitu melalui pendidikan. Pendidikan yang inklusif bagi masyarakat berkorelasi dengan hadirnya subjek-subjek kritis dimasyarakat. Dari kedua uraian diatas akhirnya dapat dilihat bentuk kontestasi pandangan budaya di dalam kongres, kategorisasi teks yang mendukung pembangunan nasional dan mengkritiknya. Pemetaan dari gagasan yang disampaikan tidak terlepas dari hegemoni politik kebudayaan nasional termasuk implikasinya dalam penggunaan istilah dan kebijakan dalam kebudayaan.

\section{Politik Kebudayaan Nasional dalam Kongres Kebudayaan Indonesia Tahun 1991}

Peneliti akan menjelaskan beberapa elemen yang membangun sebuah proses produksi budaya baik dalam level ide maupun praktik. Pertama, institusi, dalam konteks masyarakat modern dapat dipahami sebagai kata benda dan kata proses yang pada tahap tertentu mencerminkan sesuatu yang bersifat abstrak menjadi terlihat objektif dan sistematis (Raymond Williams, 1985: 170). Dalam konteks institusi yang lebih spesifik seperti hegemoni, kebudayaan, dan politik relasi yang terjadi akan terlihat semakin kompleks. Keberadaan institusi tidak hanya menggambarkan pandangan dunia dan hubungan juga sifat manusia. Secara politis, institusi memungkinkan adanya konstruksi dan ekspresi dalam melihat dunia dan diri manusia (Raymond Williams, 1985: 145).

Ada dua institusi yang akan dijelaskan dalam melihat pembentukan diskurus budaya Orde Baru dan peranannya dalam merepresentasikan kepentingan pembangunan nasional dalam bidang kebudayaan, yaitu Direktorat Kebudayaan dan TMII (Taman Mini Indonesia Indah). Perlu diingat bahwa kebijakan dan strategi kebudayaan yang dijalankan oleh pemerintahan Orde Baru adalah perencanaan yang terstuktur dalam membangun kapasitas manusia dan kekuatan nasional. Dengan demikian yang perlu dilakukan adalah melakukan “penyaringan” atas unsur - unsur yang mendukung dan tidak mendukung kepentingan tersebut. 
Mekanisme hegemoni pun diberlakukan untuk memastikan bahwa hambatan-hambatan dan kelompok oposisi pemerintah tidak mendapatkan akses dan ruang.

Ada tiga aturan yang diberlakukan oleh Direktorat Kebudayaan terkait hal tersebut, pertama, memastikan bahwa "seniman dan penyanyi memasukkan pesan pemerintah kedalam naskah/dialog dan lirik lagu mereka", kedua, tema-tema politik dihapus dan digantikan dengan cerita-cerita generik dan yang tidak bernada menyerang serta dengan pesan-pesan yang mendukung pembangunan. Ketiga, proses luas perbaikan langsung, termasuk mengurangi waktu pertunjukan, menggunakan Bahasa Indonesia dan mengubah unsur-unsur yang dianggap "tidak bermoral" (Tod Jones, 2015: 160-161). Melalui kebijakan yang diberlakukan untuk persoalan kebudayaan, Orde Baru menunjukkan sisi hegemonik dari keberadaan negara dalam kehidupan sosial masyarakat. Ide dominan mengenai pembangunan nasional yang dimanifestasikan kedalam bentuk kebudayaan nasional menjadi landasan secara politik dan kultural untuk melibatkan masyarakat dalam kemajuan bangsa.

Selanjutnya, dalam usaha untuk menciptakan harmonisasi dari pluralitas budaya daerah dan memasukkannya kedalam kebudayaan nasional, Orde Baru membuat TMII (Taman Mini Indonesia Indah). Hal ini tidak terbatas pada usaha untuk merepresentasikan pluralitas budaya, namun dalam tujuan yang lebih komprehensif adalah untuk menyajikan bentuk ideal dari kebudayaan dan manusia Indonesia. Pendirian TMII memang bertujuan menanamkan bentuk kesadaran semu atas keanekaragaman budaya Indonesia dalam konteks pembangunan. Tujuan pendiriannya sebagaimana dinyatakan pemerintah adalah untuk mendidik rakyat Indonesia tentang bangsa mereka dan diri mereka sendiri. Pada acara peresmian TMII, Soeharto mengatakan, "Dengan mengunjungi taman ini kita akan mengenal diri kita lebih baik, kita akan tahu hegemonik lebih baik dan kita akan lebih lagi mencintai tanah air kita. Oleh karena itu, Taman Mini Indonesia Indah juga merupakan upaya nyata untuk memperkuat pembangunan nasional, sekarang dan dimasa depan" (Tod Jones, 2015: 63).

Dua institusi yang telah dijelaskan diatas adalah contoh dari sekian banyak institusi yang melembagakan diskursus budaya Orde Baru. Peranannya menjadi sangat signifikan bilamana memperhatikan relasi kuasa dan praktik sosial dalam masyarakat. Dalam pemerintahan otoriterian yang menjadi sangat penting adalah membentuk subjek-subjek ideal untuk memperlancar kepentingan ekonomi politik. Serangkaian mekanisme yang dijalankan tidak secara konsekuen sesuai dengan keinginan negara atau pihak penguasa, dalam prosesnya akan dimungkinkan ada penolakan-penolakan ataupun kritik. Hal ini didasari dengan kenyataan yang ditampilkan dari kebijakan dan strategi budaya tersebut kontradiktif dengan struktur pengalaman dan pikiran masyarakat. 
Pembangunan sebagai sebuah kata kunci dalam pemerintahan Orde Baru dapat dianalisa sebagai sejarah semantik sebuah istilah dan hubungannya dengan formasi sosial dan historis yang dieksplorasi. Orde Baru memahami masyarakat Indonesia sebagai bagian dari "Negara Dunia Ketiga" yang pada saat bersamaan dianggap sebagai masyarakat "underdeveloped" (terbelakang). Pembangunan memperkenalkan metode yang pertama-tama membuat individu dapat dihitung dan kedua, memasukkan orang kedalam rezim pelatihan (Tod Jones, 2015: 135137). Formasi sosial masyarakat yang coba dibentuk dan diarahkan oleh pemerintahan Orde Baru juga berkaitan dengan percepatan modernisasi.

Logika yang digunakan adalah menganggap setiap hal yang berkaitan dengan kemajuan bangsa harus mengarah pada bentuk modern. Ideologi pembangunan yang diadopsi Indonesia melalui intelektual pendukung modernisasi, pada intinya mengenal "pembedaan yang tajam antara masyarakat tradisional dan modern" dan membangun hierarki antara keduanya yang sangat mengistimewakan masyarakat modern dan mengutuk masyarakat tradisional (Tod Jones, 2015: 142). Orde Baru memastikan upaya "menormalisasi masyarakat" sebagai bagian dari menyelamatkan bangsa Indonesia dari krisis dan perlahan menuju evolusi kebudayaan modern. Dengan memandang masyarakat Indonesia sebagai "masyarakat terbelakang”, proses depolitisasi menjadi kunci, hal ini dilakukan untuk mengekang kekuatan oposisi dan memastikan kekuatan Orde Baru secara politik bisa menjadi terpusat.

Pembangunan Indonesia ditandai oleh pergulatan antara dua kekuatan yang saling berlawanan: pertama, kemandirian yang dilandasi oleh ideologi nasionalisme, dan kedua, menempatkan Indonesia dalam kapitalisme global (Brian McCormack, 1999: 48). Keikutsertaan dalam sistem ekonomi pasar dan kapitalisme global mewajibkan Indonesia untuk menyesuaikan dengan mekanisme juga karakteristik yang berlaku secara global terutama dalam hubungan ekonomi-politik. Pada masa Orde Baru di bawah Soeharto terdapat bukti meningkatnya orientasi kapitalis baik di dalam pemerintahan maupun dimasyarakat pada umumnya. Disektor budaya, pemerintahan Orde Baru menggeser pemanfaatan bentuk-bentuk budaya kearah kepentingan ekonomi. Salah satu bentuknya dengan mengartikulasikan budaya dalam pengertian pariwisata. Meskipun pariwisata hanya sesekali disebutkan dalam bagian budaya dari setiap Repelita, kebudayaan sering disebutkan dalam bagian pariwisata baik sebagai sumber daya penting maupun sebagai objek yang membutuhkan pengelolaan cermat. Wisata budaya, besar karena pertumbuhan pariwisata di Bali, dipandang oleh rezim sebagai sumber potensial pendapatan negara (Tod Jones, 2015: 181).

Pengelolaan atau pembinaan budaya, pemanfataan teknologi, dan persaingan global menjadi istilah yang retorik untuk menanamkan kesadaran kepada masyarakat dalam rangka 
mendukung agenda pembangunan. Untuk memastikan itu proses tersebut, masyarakat dihadapkan pada wacana seperti globalisasi, modernisasi, dan persaingan. Analisis atas keberadaan institusi, formasi sosial, dan mode produksi menunjukkan adanya proses hegemonik dalam hubungan negara dan masyarakat. Kongres Kebudayaan Tahun 1991 adalah salah satu peristiwa yang menegaskan adanya hubungan kompleks terkait ide-ide dominan dan situasi sosial politik dimasyarakat. Setelah memetakan beberapa gagasan yang berkembang dalam Kongres Kebudayaan Indonesia Tahun 1991 juga menghubungkannya dengan bentukbentuk signifikansi yang ada, ditemukan adanya upaya untuk mem-produksi sebuah diskursus dominan terkait budaya dalam wacana pembangunan nasional dan kebudayaan nasional. Untuk melihat keterkaitan tersebut akan digambarkan dalam skema berikut;

\section{Skema 2}

\section{Proses Produksi Politik Kebudayaan Nasional dalam Kongres Kebudayaan Tahun 1991}

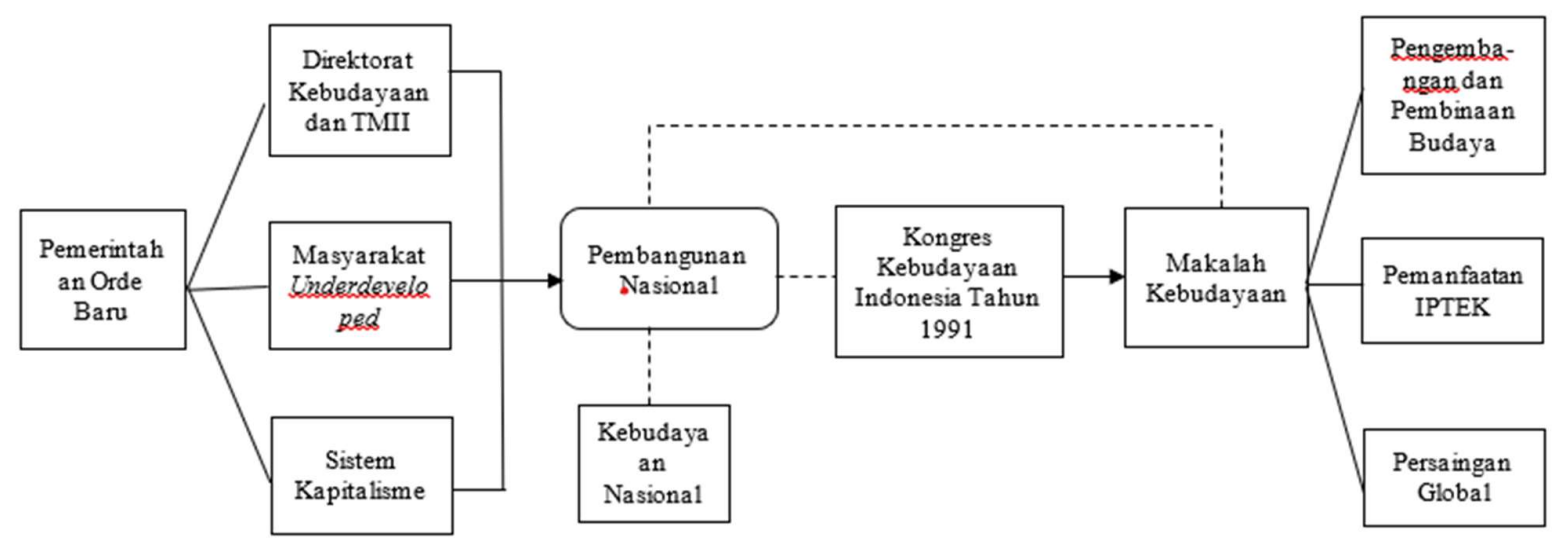

Skema diatas merupakan penggambaran proses produksi budaya pada pemerintahan Orde Baru dengan melibatkan institusi, penafsiran atas formasi sosial masyarakat dan mode produksi dalam sistem kapitalisme. Keseluruhan proses tersebut dimanifestasikan kedalam kebijakan dan strategi kebudayaan dalam konteks pembangunan nasional. Pembangunan nasional menjadi wacana yang hampir menjelaskan keseluruhan praktik dan ideologi pemerintahan. Kongres Kebudayaan Indonesia Tahun 1991 menampilkan bagaimana dalam perkembangan gagasan kebudayaan juga dipengaruhi oleh diskursus budaya dominan yang ada.

Direktorat Kebudayaan dan TMII dipilih sebagai contoh institusi yang melegitimasi diskursus budaya Orde Baru sebab secara tidak langsung kedua institusi ini merepresentasikan kehadiran negara dalam pelaksanaan kongres. Direktorat Kebudayaan adalah institusi yang secara formal menjadi penyelenggara kongres, sedangkan TMII secara semantik dapat dilihat 
sebagai manifestasi kebudayaan nasional yang ditunjukkan dengan menjadi tempat penyelenggaraan kongres. Meskipun dengan dalih untuk menciptakan demokratisasi kebudayaan juga menunjukkan perhatian negara dalam bidang kebudayaan, dua institusi ini turut mem-produksi ide-ide dominan terkait kebudayaan Orde Baru.

Formasi sosial masyarakat adalah irisan dan penggabungan keseluruhan cara hidup manusia yang tereksplorasi secara historis. Dalam pengertian ini, Orde Baru tidak menggunakan tafsir baru dalam memandang formasi sosial masyarakat, logika pembangunan yang digunakan adalah warisan dari pemahaman pemerintahan kolonial. Dengan menganggap masyarakat Indonesia masih dipengaruhi hal-hal yang bersifat tradisional dan tidak mampu menjadi subjek-subjek modern. Dasar logika itu dijadikan alasan untuk melegitimasi peran negara dan intervensinya, termasuk yang terjadi dalam masyarakat pada masa Orde Baru.

Dengan terhubungnya masyarakat Indonesia dalam sistem ekonomi global, menciptakan penyesuaian-penyesuaian terhadap kebutuhan pasar dalam praktik sosial maupun ide-ide yang berkembang. Kapasitas manusia menjadi kekuatan penting yang harus dioptimalkan dalam mendukung proses pembangunan. Pada masa pemerintahan Orde Baru, manusia Indonesia diarahkan kedalam bentuk subjek ekonomi yang terintegrasi dengan kepentingan politik. Melalui sistem ekonomi yang kapitalistik dan sentralistik, pengelolaan basis material dalam masyarakat seperti kebudayaan menjadi pendukung program-program pembangunan.

Wayan Geriya, dalam makalah kebudayaannya menyatakan bahwa kebijakan di bidang budaya untuk menunjang kebijakan makro pembangunan nasional yang dalam pengartian untuk kepentingan ekonomi. Selain itu, terkait hubungannya dengan ekonomi global atau sistem ekonomi pasar, Soemitro dan Wayan menempatkan kebudayaan daerah dan kebudayaan nasional dalam segala bentuk potensinya dapat mendukung kepentingan nasional. Penekanan utama dari gagasan keduanya adalah membangun mentalitas masyarakat yang mampu bersaing secara global.

Dalam pembahasan kebudayaan yang lebih bersifat spesifik, tokoh lainnya, yaitu Tilaar dan Barnabas melihat potensi Pancasila sebagai jawaban dan alat untuk mengatasi permasalahan kebudayaan. Menurut Barnabas, dengan konsepsi wawasan nusantara dan rekayasa sosial persoalan kontak budaya dalam masyarakat Irian Jaya dapat teratasi. Nilai-nilai moralitas yang terdapat dalam Pancasila dapat dioptimalkan untuk mengurangi dampakdampak negatif dari kontak budaya yang terjadi. Namun, berdasarkan konteks sosial politik dan kebijakan yang dterapkan oleh Orde Baru, Pancasila lebih sering digunakan untuk melakukan kontrol atas praktik kehidupan dimasyarakat. 
Berkaitan dengan itu, dibidang pendidikan, menurut Tilaar, SISDIKNAS mampu mendorong pembangunan yang berbudaya dengan menciptakan pelajar yang mampu secara optimal mengembangkan diri dan menyesuaikan diri dengan peningkatan produktvitas juga kualitas. Hal ini menurutnya akan berimplikasi pada kemajuan bangsa dalam kepentingan pembangunan nasional. Pada saat yang sama, praktik pendidikan pada masa Orde Baru memang diarahkan pada upaya menanamkan kesadaran terkait pembentukan subjek-subjek ideal yang tidak mengkritisi dan menggangu kepentingan negara.

Pandangan yang disampaikan oleh Sutan Takdir menjelaskan bahwa yang terpenting dalam hubungan budaya dalam konteks global adalah penguasaan atas ilmu pengetahuan dan teknologi yang menjadikan bangsa Indonesia dapat bersaing dengan negara-negara lainnya. Menurutnya, globalisasi yang akan dihadapi oleh bangsa Indonesia kedepannya mengharuskannya untuk menyerap segala pengetahuan Barat.

Signifikasi dari pandangan budaya yang disampaikan oleh pemakalah diatas secara tidak langsung turut mem-produksi ide dominan terkait kebudayaan ala Orde Baru. Tokoh-tokoh tersebut mengeksplorasi ide kebudayaan nasional yang berfokus pada pemeliharaan, pembinaan, dan pengembangan budaya untuk kemajuan sekaligus kepentingan ekonomi. Soemitro menggunakan istilah "nation and character building" untuk menjelaskan arah pengembangan budaya masyarakat dengan tujuan menghindari bentuk-bentuk negatif bagi pembangunan. Baginya persaingan bebas dan liberalisme menjadi bentuk konkrit bagi kemajuan ekonomi bangsa.

Pandangan dari kelima tokoh diatas melegitimasi sekaligus mengkonstruksi ide kebudayaan nasional dengan menempatkan aspek budaya pada struktur masyarakat kedalam kerangka pembangunan nasional Orde Baru. Pandangan sebagai bentuk ide adalah bagian dari produksi budaya, meskipun tidak secara langsung berdampak bagi kehidupan masyarakat, namun bila diperhatikan ide-ide yang berkembang akan selaras dengan arah kebijakan dan strategi kebudayaan Orde Baru.

\section{Kongres Kebudayaan Indonesia Tahun 1991 dan Kritik terhadap Politik Kebudayaan Nasional}

Kongres Kebudayaan Indonesia Tahun 1991 tidak hanya berhubungan dalam proses produksi budaya, tetapi pada saat yang bersamaan kongres pun memungkinkan terjadinya proses reproduksi budaya. Istilah reproduksi umumnya digunakan untuk menjelaskan bentukbentuk "peniruan" dan penciptaan organisme baru (biologis). Namun, ketika kata itu digunakan untuk menjelaskan proses budaya, dalam budaya seperti dalam aktivitas sosial yang lebih umum, dan telah diakui reproduksi sistematis dari kedalaman tertentu harus melihat bahwa 
tatanan sosial dan tatanan budaya secara aktif (Raymond Williams, 1995: 201). Pemahaman tersebut memberikan kesempatan untuk menciptakan pembaharuan dibidang budaya.

Proses reproduksi budaya dapat dijelaskan dalam dua hal, melalui pendidikan dan tradisi. Terkait reproduksi budaya (gagasan budaya) dalam Kongres Kebudayaan Indonesia Tahun 1991 lebih dijelaskan melalui pemahaman tradisi. Tradisi merupakan proses kesinambungan yang disengaja, namun tradisi apa pun dapat ditunjukkan, melalui analisis, sebagai seleksi dan pemilihan kembali elemen penting yang diterima dan dipulihkan dari masa lalu yang tidak mewakili kebutuhan tetapi keinginan (Raymond Williams, 1995: 187). Kongres kebudayaan merupakan bagian dari tradisi sejarah perkembangan kebudayaan Indonesia, dilakukan secara berkelanjutan dalam periode pemerintahan yang berlangsung di Indonesia. Didalamnya ada upaya rekonsiliasi untuk merumuskan wacana kebudayaan dan alternatif pilihan untuk mengatasi permasalahan budaya.

Kongres Kebudayaan mereproduksi nilai dan makna terkait demokratisasi kebudayaan. Sepanjang pelaksanaan kongres, gagasan yang berkembang merupakan respon atas kondisi sosial budaya dimasyarakat. Sebagai contoh, pendapat Ki Hajar Dewantara mengenai bahasa sebagai alat kebudayaan, Ia menekankan pentingnya pengakuan dan penggunaan Bahasa Indonesia oleh pemerintahan kolonial dalam hubungan birokratif dengan masyarakat pada saat itu. Dalam Kongres Kebudayaan Indonesia Tahun 1951 juga berkembang gagasan perihal penyediaan balai penerbitan untuk buku-buku yang tidak bersifat komersil juga pendirian balai sastra di daerah-daerah untuk mendukung penyebaran akses bacaan kepada masyarakat.

Secara historis, kongres kebudayaan juga berkaitan dalam menghasilkan gagasan yang tidak terkualifikasi oleh diskursus budaya dominan. Hal ini didasari dengan melihat hegemoni sebagai sebuah proses yang terhubung dengan "pengalaman" dan "cara pandang" komunitas masyarakat atas realitasnya. Realitas dari setiap hegemoni, dalam arti politik dan budaya yang luas, adalah bahwa, meskipun menurut definisi selalu mendominasi, tetap tidak pernah total atau eksklusif. Setiap saat, bentuk-bentuk politik dan budaya alternatif atau oposisi langsung muncul sebagai elemen penting dalam masyarakat (Raymond Williams, 1995: 113). Kongres Kebudayaan Tahun 1991 menjadi medium dalam menyampaikan gagasan alternatif dan berlawan dengan ide-ide budaya dominan.

\section{Skema 4.2}




\section{Skema Kritik Politik Kebudayaan Nasional dalam Kongres Kebudayaan Indonesia}

Tahun 1991

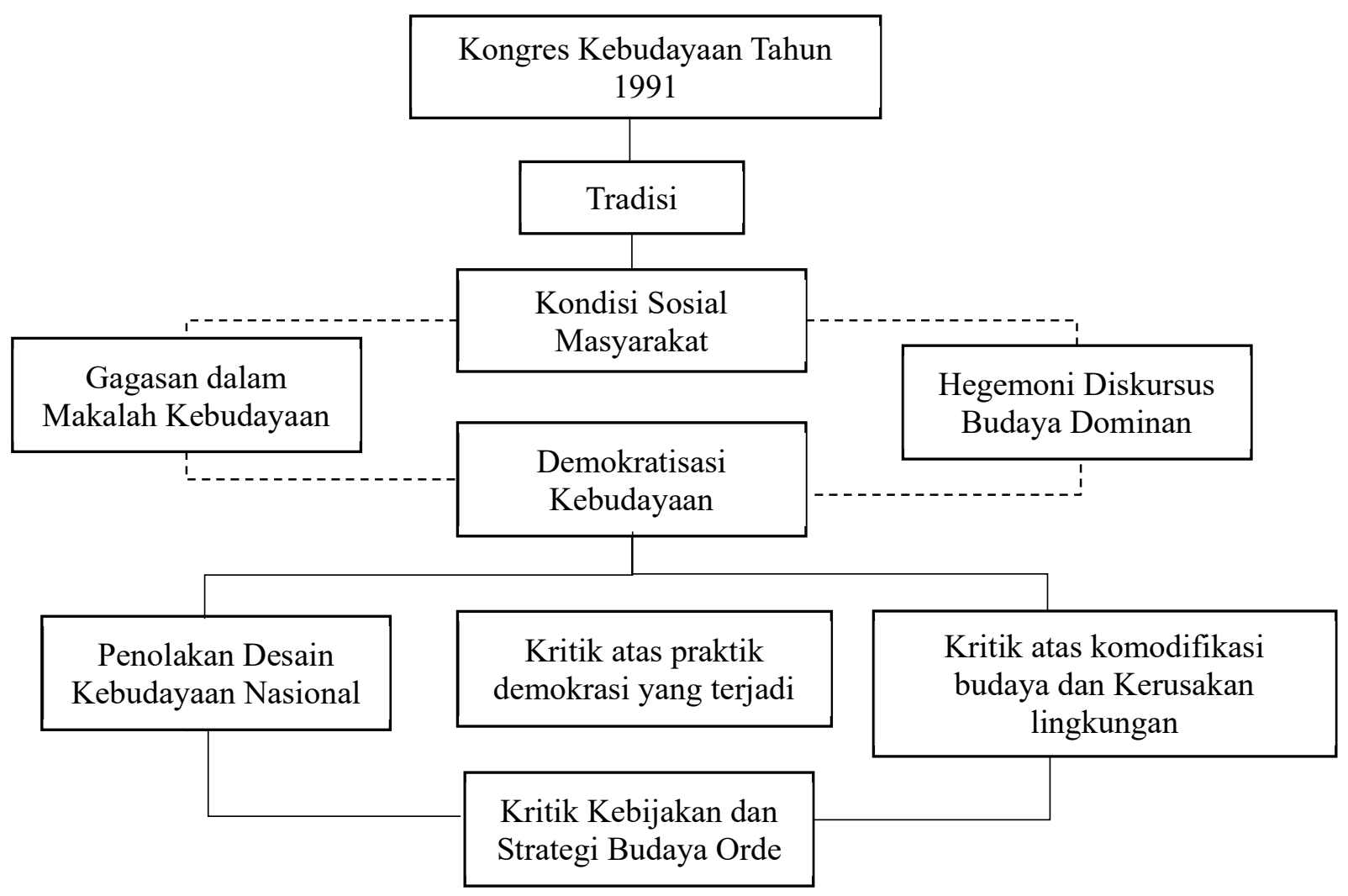

Nirwan Dewanto menolak gagasan desain kebudayaan nasional Orde Baru, menurutnya tidak ada bentuk tunggal dan kekuatan determinan yang membentuk kebudayaan. Kebudayaan secara aktif berkembang dan hidup dari pengalaman-pengalaman yang hidup dalam komunitas masyarakat. Melalui pengandaian kebudayaan seperti hutan, dan kita melihatnya dari atas pesawat terbang, yang tampak hanya bagian "luar" dari keseluruhan bentuk kehidupan organisme didalamnya. Untuk melihat bentuk-bentuk spesifik dari "organisme" didalamnya hanya bisa dilakukan dengan penelusuran yang menyeluruh. Ia juga menegaskan untuk kembali melihat posisi subjek sebagai elemen penting dalam proses perkembangan budaya.

Gagasan lainnya yang mengkritik praktik-praktik pemeritahan Orde Baru adalah W.S. Rendra. Rendra bersikap kritis dari menurunnya daya hidup dimasyarakat, Ia melihat salah satu faktor yang mempengaruhi adalah mentalitas para birokrat yang tidak mendukung proses kebudayaan dimasyarakat. Menurutnya, kesulitan dalam menjaga daya hidup didalam kebudayaan kita adalah kurang luasnya demokrasi didalam kehidupan berbangsa. Karena kurang luasnya demokrasi itulah maka kebudayaan instruksi dan indoktrinasi bisa merajalela. Sehingga bila ada krisis dalam proses demokrasi, maka segera orang kembali kepada naluri 
penguasa. Keadaan yang memperkukuh erosi demokrasi ini makin menjadi setelah kaum politis menciptakan keadaan-keadaan darurat.

Umar Kayam menyoroti hal serupa dengan Rendra, menurutnya permasalahan yang terjadi dalam hubungan negara dan masyarakat adalah tidak adanya ruang kontrol yang diberikan kepada masyarakat kepada pemerintah sekaligus juga terlalu kuatnya dominasi kekuatan politik negara dalam mengontrol segala urusan masyarakat. Kondisi yang demokratis terkait bidang budaya, sosial, politik, bahkan pendidikan belum sepenuhnya terciptanya. Ia pun menegaskan bahwa dalam mengembangkan dan memajukan kebudayaan nasional dapat dilakukan melalui pencarian dan pembentukan unsur-unsur baru tanpa menghilangkan nilainilai dalam kebudayaan daerah.

Kritik lainnya yang disampaikan terkait politik kebudayaan nasional disampaikan oleh Arief Budiman, menurutnya, sistem kapitalisme yang berlaku di Indonesia memberikan dampak buruk bagi kehidupan masyarakat, salah satunya adalah perampasan tanah dan ruang hidup masyarakat dalam proses pembangunan. Disamping itu, kepentingan pembangunan nasional yang diproyeksikan sebagai pembangunan berbudaya, menurutnya, hanyalah kepentingan dari kelas berkuasa melalui perluasan fasilitas-fasilitas industri yang kemudian dianggap sebagai kepentingan nasional.

Kondisi sosial politik yang terpengaruh atas kebijakan dan strategi kebudayaan menjadi perhatian beberapa tokoh untuk mengkritisi akar permasalahan yang terjadi. Mangunwijaya dalam gagasannya terkait kebudayaan menjelaskan pentingnya keberadaan sains dan teknologi dimasyarakat. Berbeda dari apa yang dimengerti oleh Orde Baru terkait pemanfaatan sains dan teknologi, Mangunwijaya berfokus pada subjek-subjek yang kritis dan mampu membangun proses dialektis dengan juga "membahayakan kaum mapan". Hal tersebut dimungkinkan dengan adanya struktur dan iklim sosial politik yang demokratis, masyarakat mendapatkan akses untuk melakukan pengawasan dan kritik kepada pemerintahan. Menurutnya semua itu masih perlu diupayakan, sebab iklim sosial dan politik masih didominasi oleh pemerintahan dan kelompok militer.

Kritik atas hubungan budaya dan pembangunan juga disampaikan oleh Dawam Rahardjo, terkait pergeseran orientasi dalam pemanfaatan budaya menurutnya memberikan dampak yang cukup signifikan bagi kehidupan masyarakat. Kesenian telah dimasukkan kedalam agenda para turis. Kesenian secara terang-terang telah dijadikan barang dagangan. Sungguhpun demikian, kesenian memang menjadi "hidup", karena dihidupi oleh kegiatan turisme, walaupun kesenian, sebagaimana pantai-pantai di Bali yang indah selagi murni, dinilai telah terkena polusi dan perusakan lingkungan hidup. 
Gagasan yang mengkritik dampak kebijakan dan strategi kebudayaan Orde Baru diatas adalah bentuk kontra - wacana atas dominasi ide dominan. Gagasan tersebut juga merepresentasikan adanya upaya untuk menjadikan Kongres Kebudayaan Indonesia tahun 1991 menjadi alternatif praktik budaya yang terbebas dari kepentingan negara. Sebagai sebuah peristiwa sejarah, Kongres Kebudayaan Indonesia tahun 1991 mereproduksi nilai demokratisasi budaya. Hal ini dapat dipahami dengan melihat kenyataan historis bahwa pelaksanaan kongres selalu menghasilkan gagasan yang inklusif juga objektif terkait kebudayaan.

Diskursus budaya Orde Baru yang diperlihatkan melalui kebijakan dan strategi kebudayaannya, menurut pandangan beberapa tokoh diatas tidak relevan bahkan tidak memiliki signifikansi yang kuat. Sebab, pembentukan wacana tunggal atas kebudayaan yang menjadi faktor pendukung pembangunan menimbulkan dampak-dampak yang merugikan bagi kehidupan sosial dimasyarakat. Dari gagasan yang mengkritik diskursus budaya Orde Baru juga dapat dikatakan adanya hubungan diantara pelaksanaan kongres terkait esensinya untuk menciptakan demokratisasi budaya. Bahwa gagasan yang berkembang didalam kongres bukanlah perihal kepentingan politik suatu pemerintahan tetapi respon atas kondisi rill dimasyarakat.

Pandangan budaya yang disampaikan oleh keenam tokoh diatas adalah upaya counter hegemony dengan menunjukkan realitas dari praktik budaya yang dilakukan Orde Baru bagi masyarakat. Kritik yang disampaikan melalui pandangan tokoh-tokoh diatas meretas jalan baru bagi pemahaman terkait kondisi kultural dimasyarakat. Berbagai perspektif alternatif disampaikan untuk mengurangi tekanan dan dominasi dari wacana kebudayaan dominan.

\section{Penutup}

Kontestasi pandangan budaya dalam Kongres Kebudayaan Indonesia Tahun 1991 dilihat berdasarkan pada gagasan yang mendukung wacana pembangunan nasional dan mengkritik dampak-dampak dari kebijakan pembangunan nasional. Terkait gagasan yang mendukung wacana pembangunan nasional dapat dilihat melalui makalah kebudayaan yang disampaikan oleh Barbanas Suebu, Wayan Geriya, Soemitro, H.A.R Tilaar, dan Sutan Takdir Alihsjahbana. Tokoh-tokoh tersebut memandang bahwa pembangunan nasional merupakan alternatif pilihan bagi pengembangan dan pemajuan kebudayaan dimasyarakat. Kritik atas wacana pembangunan nasional disampaikan oleh enam tokoh, yaitu, Nirwan Dewanto, W.S. Rendra, Umar Kayam, Mangunwijaya, Dawam Rahardjo, dan Arief Budiman. Keenam tokoh tersebut mencoba memberikan sudut pandang lain terkait persoalan kebudayaan masyarakat yang tidak dibatasi pada konsepsi tunggal negara. 
Kongres Kebudayaan Indonesia Tahun 1991 melegitimasi politik kebudayaan nasional Orde Baru dilihat berdasarkan peran Direktorat Kebudayaan dan TMII, penafsirannya atas formasi sosial masyarakat yang terbelakang, dan mode produksi dengan sistem kapitalisme. Kongres Kebudayaan Tahun 1991 adalah sebuah tradisi yang berkaitan dengan proses reproduksi diskursus budaya. Dengan melihat adanya nilai demokratisasi budaya sepanjang sejarah pelaksanaan kongres kebudayaan, gagasan yang berkembang didalam Kongres Kebudayaan Indonesia tahun 1991 tidak seluruhnya bersifat mendukung terhadap politik kebudayaan nasional Orde Baru dan membuktikan juga bahwa dari kebijakan dan strategi kebudayaannya tidak relevan bagi kehidupan sosial masyarakat.

\section{Daftar Pustaka}

Departemen Pendidikan dan Kebudayaan, Direktorat Jenderal Kebudayaan, Direktorat Sejarah dan Nilai Tradisional. 1992. Kongres Kebudayaan 1991: Warisan Budaya: Penyaringan dan (Buku I). Jakarta: Departemen Pendidikan dan Kebudayaan, Direktorat Jenderal Kebudayaan, Direktorat Sejarah dan Nilai Tradisional.

1992. Kongres Kebudayaan 1991: Kebudayaan Nasional; Kini dan di Masa Depan (Buku II). Jakarta: Departemen Pendidikan dan Kebudayaan, Direktorat Jenderal Kebudayaan, Direktorat Sejarah dan Nilai Tradisional.

1992. Kongres Kebudayaan 1991: Daya Cipta dan Perkembangan Budaya (Buku III). Jakarta: Departemen Pendidikan dan Kebudayaan, Direktorat Jenderal Kebudayaan, Direktorat Sejarah dan Nilai Tradisional.

1992. Kongres Kebudayaan 1991: Kebudayaan dan Sektor - Sektor Kehidupan Masyarakat (Buku IV). Departemen Pendidikan dan Kebudayaan, Direktorat Jenderal Kebudayaan, Direktorat Sejarah dan Nilai Tradisional: Jakarta.

1992. Kongres Kebudayaan 1991: Kebudayaan Indonesia dan Dunia (Umat Manusia) (Buku V). Jakarta: Departemen Pendidikan dan Kebudayaan, Direktorat Jenderal Kebudayaan.

.1992. Kongres Kebudayaan 1991: Laporan Penyelenggaraan. Jakarta: Departemen Pendidikan dan Kebudayaan, Direktorat Jenderal Kebudayaan, Direktorat Sejarah dan Nilai Tradisional.

Goncalves G, Maria Paola. A Cultural Decade: Reflections on The World Decade for Cultural Development 1988 - 1997. Paris: Studies and Reports of the Unit of Cultural Research and Management - No. 5.

Jones, Tod. 2015. Kebudayaan dan Kekuasaan di Indonesia Kebijakan Budaya Selama Abad Ke-20 Hingga Era Reformasi. Jakarta: Yayasan Pustaka Obor Indonesia.

Kovala, Urpo. 2002. Cultural Studies and Cultural Text Analysis, Jurnal CLCWEB: Comparative Literatur and Culture, Volume 4 Issue 4. USA: Purdue University Press. Diakses melalui

laman 
https://docs.lib.purdue.edu/cgi/viewcontent.cgi?article=1169\&context=clcweb pada tanggal 3 Juni 2019 pukul 22.46 WIB.

Lehtonen, Mikko. 2000. The Cultural Analysis of Text. London: SAGE Publications.

McCormack, Brian. 1999. Fifty Years of Indonesian Development: "One Nation" Under Capitalism. Department of Political Science: Arizona State University. Journal of World System Research Volume 5. Diakses dari laman http:/jwsr.pitt.edu/ojs/jwsr/article/view/146/158.

Supardi, Nunus. 2007. Kongres Kebudayaan (1918 - 2003). Jakarta: Ombak.

Supardi, Nunus. 2016. Melacak Jejak Direktur Jenderal Kebudayaan (Setengah Abad Direktorat Jenderal Kebudayaan 1966 - 2016). Jakarta: Direktorat Jenderal Kebudayaan, Kementerian Pendidikan dan Kebudayaan.

2013. Bianglala Budaya: Rekam Jejak 95 Tahun Kongres Kebudayaan 1918 - 2013. Direktorat Jenderal Kebudayaan, Kementerian Pendidikan dan Kebudayaan: Jakarta.

Williams, Raymond. 1995. The Sociology of Culture. USA: The University of Chicago. 1985. Keywords: A Vocabulary of Culture and Society. Oxford University Press: 200 Madison Avenue, New York.

\section{Internet}

http://ensiklopedia.kemdikbud.go.id/sastra/artikel/Sutan_Takdir_Alisjahbana

https://www.kapanlagi.com/nirwan-dewanto/profil/

https://www.papua.go.id/view-detail-tokoh-12/undefined

http://ensiklopedia.kemdikbud.go.id/sastra/artikel/Umar_Kayam

https://kebudayaan.kemdikbud.go.id/bpnbbali/wayan-geriya-strategi-dan-implementasiundang-undang-pemajuan-kebudayaan-di-bali/,

https://indonesiatera.com/prof-dr-har-tilaar-msced/,

https://www.suara.com/news/2020/09/18/184402/profil-arief-budiman-ketua-kpu-ri-daripendidikan-hingga-karier

https://www.merdeka.com/dawam-rahardjo/profil/

https://www.biografiku.com/biografi-ws-rendra/

https://initu.id/biografi-soemitro-djojohadikoesoemo-begawan-ekonomi-indonesia/

http://ensiklopedia.kemdikbud.go.id/sastra/artikel/Y_B_Mangunwijaya 